\title{
The Contribution Of Sculptor Artist (Edhi Sunarso) To The Development Of Indonesia
}

\author{
Donny Trihanondo, M.Ds. ${ }^{1}$, Didit Endriawan, M.Sn. ${ }^{2}$, \\ Teddy Ageng Maulana, M.Sn. ${ }^{3}$, Tri Haryotedjo, M.Ds. ${ }^{4}$ \\ ${ }^{1}$ Telkom University, donnytri@telkomuniversity.ac.id, \\ ${ }^{2}$ Telkom University, didit@tcis.telkomuniversity.ac.id, \\ ${ }^{3}$ Telkom University, teddy@tcis.telkomuniversity.ac.id, \\ ${ }^{4}$ Telkom University, triharyotedjo@tcis.telkomuniversity.ac.id,
}

\begin{abstract}
Edhi Sunarso is one of the well-known sculptors in Indonesia. There are a lot of monumental works had been created by Edhi Sunarso in strategic places in Indonesia. Edhi Sunarso had produced works that would become a symbol of a historic memorial in Indonesia. There are works such as the West Irian Liberation Monument in Jakarta, Sacred Pancasila Monument (Pancasila Sakti) Lubang Buaya, Selamat Datang Monument, Dirgantara Monument (also known as Gatot Kaca Monument) in Jakarta, Tugu Muda Monument in Semarang, General Achmad Yani Monument in Bandung, General Gatot Subroto Monument in Surakarta, Yos Sudarso Monument in Surabaya, and others. The concepts of creation in the works of Edhi Sunarso were influenced by the thought of the First President of the Republic of Indonesia, namely Bung Karno. One of them was a statue of West Irian Liberation, which described the struggles of West Irian (Papua) to be free from Dutch colonial rule.

This study examines the works of Edhi Sunarso with the method of art criticism and the scientific approach of Sociology of Art. With these two scientific approachs, this research is expected to give new insight to the public about the role of Edhi Sunarso as an artist in the development of the Indonesian nation in particular and for the international world in general. Besides that, this research could also enrich the culture and thought for the development of art in Indonesia.
\end{abstract}

Keyword: role of artist, Edhi Sunarso, statue, Monumental, Bung Karno

\section{Introduction}

Speaking of sculpture in Indonesia cannot be separated from the name of one of Indonesia's great artists, Edhi Sunarso. His works are much admired by sculpture lovers. Art is a thing that is applicable and universal value. No one does not like art. And conversely, not many people have artistic skills and talents. And only a few people are also among those who have the talent and expertise that managed to record history monumentally because of its considerable service in improving and fostering the national culture.

\section{The Role of Edhi Sunarso in the Development of Indonesia}

Edhi Sunarso plays a big role in the history of Indonesia's development. His role is mainly in the field of fine arts especially art. His sculptural works serve as a historical monument, a monument that can affect the nation's mentality with the concept of Nation and Character Building from Bung Karno's point of view. The statues made by Edhi Sunarso were Soekarno's expressions of love for his homeland, Indonesia. Soekarno's expressions were then manifested in sculpture through an artist named Edhi Sunarso. The works of Edhi Sunarso's statues are placed in strategic locations in Indonesia. 


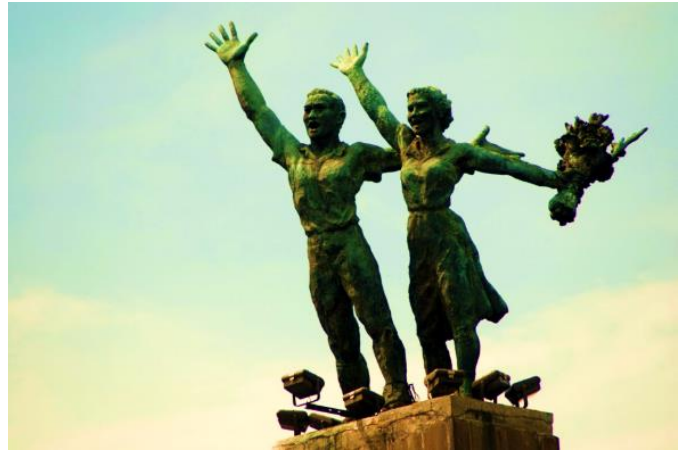

Name

: Selamat Datang Monument Year Completed : 1962

Sculpture's Height : 8,5 meters (from feet to hands)

Foundation's Height: 10 meters

Material : Bronze

This monument was made to welcome the Asian Games IV in Gelora Bung Karno in 1962. The idea of this statue was triggered by President Sukarno with the politics of the lighthouse. This statue consists of a pair of young men who welcome people coming from the direction of the National Monument. The lady on the monument holds a bouquet of flowers. The initial draft sketch of this statue was done by Henk Ngantung, who was Vice Governor of Jakarta at that time. The production of the statue was led by Edhi Sunarso with direct supervision by President Sukarno. The making of the statue took about a year.

This monument is located right in the middle of the Hotel Indonesia roundabout in the city of Jakarta, becoming the icon of the capital of the Republic of Indonesia until today. At that time, President Sukarno directly requested Edhi Sunarso to make this Monument, but at the beginning, Edhi Sunarso actually refused because he felt unable to complete the project. President Sukarno then forced him, saying that if Edhi Sunarso loved the Republic of Indonesia, he would immediately carry out Soekarno's request.

Edhi then contacted his friends, including the veterans of Djawatan Keretapi, to produce the statue, the foundry was done with simple and available tools, but eventually the project could be finished well and on time. This work was the first monument entrusted to Edhi Sunarso. Since that, Edhi Sunarso became President Sukarno's trusted artist to work on other monument projects, in accordance with President Sukarno's lighthouse politics.

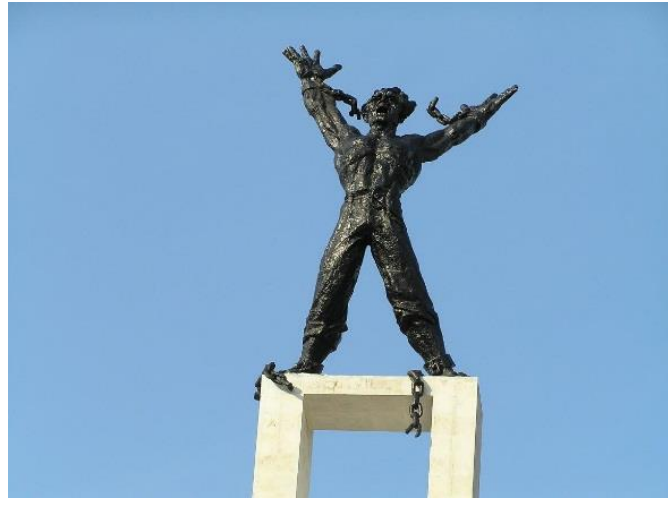

Name : West Irian Liberation Monument

Year Completed : 1963

Sculpture's Height : 11 meters (from feet to hands)

Foundation's Height : 15 meters

Material : Bronze

This statue was based on the idea that President Sukarno initiated during his speech in Yogyakarta as he mobilized the masses to liberate West Irian. The idea was then translated in sketch by Henk Ngantung. As well as Selamat Datang Monument, the project leader was entrusted to Edhi Sunarso. The size of this statue is higher when compared with the Selamat Datang Monument.

Since the making of this statue, the name of Edhi Sunarso began to skyrocket and many people started to trust him to make statues in many part of Indonesia. This statue does have a different aura from other statues in Jakarta. This statue has a historical value in commemorating the struggle of the Indonesian people to seize West Irian from the Dutch colonialists. This statue depicts a person who has been free from bondage.

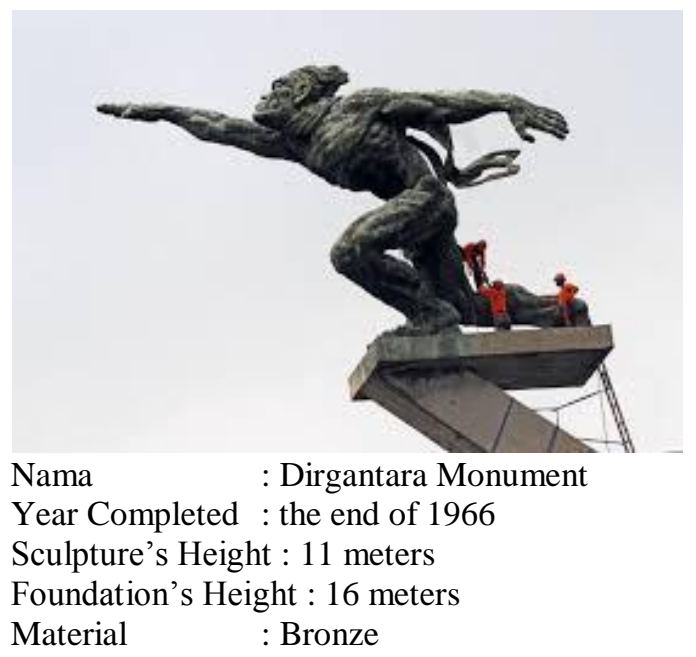


This monument is located in the vicinity of Pancoran, South Jakarta. This statue was originally an idea of President Sukarno. He wanted to make a monument that welcomes the new arrivals arriving from Halim Perdanakusuma airport. This statue depicts an aerospace man, which describes the mastery of the Indonesian nation in aerospace.

Edhi Sunarso designed this statue from 1964 to 1965 . The work of this statue had experienced obstacles due to the G30S incident, a failed PKI (The Communist Party of Indonesia) coup. However, the monument was completed at the end of 1966. The process of building the statue was often inspected directly by Bung Karno, which often made the security forces overwhelmed.

In terms of materials and techniques used, the statue was not much different from the statues of Edhi Sunarso's work before. The difference was only in the process of work in the field, Edhi Sunarso was assisted by contractors of PT. Hutama Karya and Ir. Sutami. This monument depicts the Indonesian mastery of aerospace in Indonesia, marked by the possession of Defense System Main Device owned by Indonesia at the time, in the form of Strategic Intercept Mig-21 and Mig-19, as well as Tupolev bombers, which made the Dutch yeilded for air war against Indonesia in the Irian Jaya dispute which until 1962 was still controlled by the Dutch.

\section{Closing}

Edhi Sunarso is a very influential sculptor in Indonesia. The concept in some of his works is greatly influenced by the idea of Bung
Karno. Some of these works are: the West Irian Liberation Monument, the Welcome Monument, the Aerospace Monument (Monument Aerospace), and others.

The West Irian Liberation Monument illustrates the great struggle for the liberation of West Irian at the time. The definition of liberation in question is free of Dutch colonial grip. The Welcome Monument is made with a greeting concept of welcoming overseas guests who come to Indonesia. The monumental statue mentioned above is located in the capital city of Indonesia, Jakarta, which has also contributed greatly from Governor Henk Ngantung who has a background in art in the development and creation of Edhi Sunarso's works.

Edhi Sunarso's work shows a sense of nationalism as an Indonesian nation whose concepts and skills can be compared boldly against other developed countries around the world. Edhi Sunarso is also a good example for the Indonesian people to produce works that can be widely appreciated by the community and can be passed on from time to time.

\section{Bibliography}

Djelantik, A.A.M. (1999). Estetika Sebuah Pengantar. Masyarakat Seni Pertunjukan Indonesia

Feldman, E. B. (1967). Art As Image And Idea, Prince-Hall, INC., Englewood Cliff, New Jersey.

Sumardjo, Jakob. (2000). Filsafat Seni. Bandung: Penerbit ITB 